\title{
The occurrence of rhizobacteria from Paspalum genotypes and their effects on plant
} growth

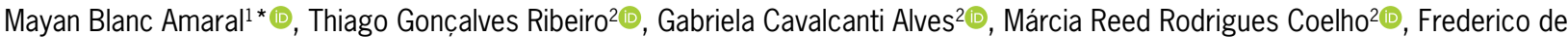 \\ Pina Matta ${ }^{3}$, José Ivo Baldani2 ${ }^{20}$, Vera Lúcia Divan Baldani2(i)
}

1Universidade Federal Rural do Rio de Janeiro/Instituto de Agronomia - Depto. de Solos, BR 465, km 07 - 23890-000

- Seropédica, RJ - Brasil.

Embrapa Agrobiologia, BR 465, km 07 - 23890-000 -

Seropédica, RJ - Brasil.

${ }^{3}$ Embrapa Pecuária Sudeste, Rod. Washington Luiz, km 234

- 13560-970 - São Carlos, SP - Brasil.

*Corresponding author <mayan_gbi@hotmail.com>

Edited by: Fernando Dini Andreote

Received August 05, 2020

Accepted December 07, 2020
ABSTRACT: This work aimed to isolate and characterize plant growth promoting rhizobacteria (PGPR) from 10 Paspalum genotypes and evaluate the effect of their inoculation on $P$. regnellii, $P$. atratum, and $P$. malacophyllum genotypes. The bacterial population ranged from undetectable to $10^{7}$ bacterial cells per gram of fresh matter in the Paspalum genotypes. Initially, we isolated 164 bacteria from rhizospheric soil and roots of the Paspalum genotypes using media $\mathrm{N}$-free LG agar plate, semi-solid NFb, and LGl. The isolates were characterized genetically and physiologically. The sequencing of 16S rRNA showed the presence of many genera, and some are new in association with Paspalum. The most common was Bacillus followed by Rhizobium, Paraburkholderia, Enterobacter, Cupriavidus, Pseudomonas, Dyadobacter and Acinetobacter. Thirty-eight per cent of isolates produced siderophores, $25 \%$ produced solubilized phosphate, and only $9 \%$ produced indolic compounds. Three greenhouse experiments were performed in randomized blocks with six replicates using representative bacterial strains isolated from $P$. regnellii, $P$. malacophyllum and $P$. atratum cv. Pojuca. We also included strain Sp245 (Azospirillum baldaniorum), uninoculated control, and nitrogen control (150 kg N ha-1). There was an increase of up to $53 \%$ in shoot dry matter in $P$. regnellii inoculated with strain Sp245 and the shoots accumulated more N. In contrast, only small effects were observed for the other Paspalum genotypes inoculated with PGPR from the host genotypes. This study shows a high diversity of diazotrophic rhizosphere bacteria and suggests no strain specificity between the bacterial isolates and the Paspalum genotypes.

Keywords: PGPR, biofertilizer, tropical grasslands

\section{Introduction}

Brazil has the largest commercial cattle herd in the world, mainly pasture-based. There are about 160 million ha of pastureland in Brazil cultivated with $80 \%$ of Brachiaria (syn. Urochloa) species, which might diminish genetic resistance to pests and diseases (USDA, 2020). On the other hand, the genus Paspalum is native to the Americas and is considered an alternative for diversification in Brazilian cultivated pastures (Manzur et al., 2020; Marques et al., 2020).

Soil bacteria benefit soil properties and plants and can be an alternative $\mathrm{N}$ source in tropical grasslands. Many bacterial genera associated to various managed grassland ecosystems are classified as diazotrophic bacteria, belonging to genera Azospirillum, Azotobacter, Rhizobium, Bacillus, Pseudomonas, and others (Antunes et al., 2019; Döbereiner, 1966; Ribeiro et al., 2020; Souza et al., 2017).

Plant Growth Promoting Rhizobacteria (PGPR) fix $\mathrm{N}$, enhance production of different enzymes that stimulate plant development, aid solubilization of nutrients, and increase production of different phytohormones and other metabolites, such as siderophores, which are antagonistic to pathogens (Backer et al., 2018; Ribeiro et al., 2020).

However, few studies have investigated the PGPR occurrence associated to Paspalum genotypes and their potential contribution as biofertilizer to grass pastures
(Baldani and Baldani, 2005; Döbereiner, 1966; Prabha et al., 2019). This study, therefore, aimed to isolate and characterize rhizobacteria from 10 Paspalum genotypes and evaluate the effect of PGPR inoculation on $P$. regnellii, $P$. atratum, and $P$. malacophyllum genotypes.

\section{Materials and Methods}

\section{Counts of culturable diazotrophic rhizobacterial population}

The study analyzed 10 Paspalum genotypes: Paspalum notatum BGP 318, Paspalum notatum BGP 155, Paspalum modestum BGP 032, Paspalum regnelliii BGP 215, Paspalum guenoarum BGP 011, Paspalum regnelliii BGP 344, Paspalum virgatum BGP 343, Paspalum plicatulum. BGP 164, Paspalum malacophyllum BGP 293, and $P$. atratum cv. Pojuca BGP 098, which were collected from the Germplasm Active Bank-GAB (21 ${ }^{\circ} 57^{\prime}$ S, 47 $7^{\circ} 56^{\prime}$ W, altitude of $856 \mathrm{~m}$ ), São Carlos, São Paulo (Brazil). The GAB was kept in a Typical Red Clay Latosol and fertilized annually with $\mathrm{N}, \mathrm{P}, \mathrm{K}$, and S.

The plants containing rhizospheric soil were collected in polyethylene bags and transported to Seropédica, Rio de Janeiro, Brazil. The plants were conditioned in pots containing $5 \mathrm{~kg}$ of sterilized sand and vermiculite (1:1) and kept in a greenhouse. The aerial part was cut and after 15 days, a nutrient solution was added 
with $30 \mathrm{~mL}$ of $\mathrm{KH}_{2} \mathrm{PO}_{4}\left(35 \mathrm{~g} \mathrm{~L}^{-1}\right), 5 \mathrm{~mL}$ of $\mathrm{CaCl}_{2} \cdot 2 \mathrm{H}_{2} \mathrm{O}$ $\left(150 \mathrm{~g} \mathrm{~L}^{-1}\right)$, and $5 \mathrm{~mL}$ of $\mathrm{MnSO}_{4} \mathrm{H}_{2} \mathrm{O}\left(5 \mathrm{~g} \mathrm{~L}^{-1}\right)$. The plants were kept in the solution until the bacterial isolating process, which occurred within two weeks.

The plants were collected and the rhizospheric soil was removed manually from air-dried roots. The roots were washed three times in sterile distilled water before processing. The rhizospheric soil and root samples (5 g) were homogenized with $45 \mathrm{~mL}$ of saline solution and then macerated with a pestle and a mortar. The samples were serially diluted up to $10^{-6}$ for root and rhizospheric soil. Then, an aliquot of $0.1 \mathrm{~mL}$ of dilutions $10^{-4}$ to $10^{-6}$ was used to inoculate, in triplicate, Petri dishes containing $25 \mathrm{~mL}$ of semi-selective solid LG medium for Azotobacter spp. Moreover, diluted samples $(0.1 \mathrm{~mL})$ were inoculated in flasks containing $5 \mathrm{~mL}$ of media of semi-selective semisolid $\mathrm{NFb}$ (0.5\% malic acid) and LGI $(0.5 \%$ sucrose) in order to count the diazotrophic bacteria population of genera Azospirillum and Nitrospirillum, respectively (Baldani et al., 2014).

The flasks inoculated with penicillin were incubated at $30{ }^{\circ} \mathrm{C}$ for five days and the pellicle formation on the medium subsurface was observed, characteristic of associative diazotrophic bacteria. After three successive culturing in the semisolid media, the pellicles were streaked out on solid agar plate media ( $\mathrm{NFb}$ and LGI) added with $40 \mathrm{mg} \mathrm{L}^{-1}$ of yeast extract and incubated at $30{ }^{\circ} \mathrm{C}$ for five days. Colonies were inoculated into a fresh semisolid medium to check again the formation of the subsurface pellicle, followed by purification in a medium of Batata-Dextrose Agar (BDA) (Baldani et al., 2014).

The diazotrophic bacteria were quantified using the Most Probable Number (MPN) technique applying the McCrady table (Baldani et al., 2014) and by counting the colony-forming units (CFU).

\section{Molecular characterization}

We selected 74 bacterial isolates based on morphocultural characteristics and used for molecular characterization. Genomic DNA extraction was performed using the Genomic DNA purification Kit according to specifications of the manufacturer. The polymerase chain reaction (PCR) technique was used for amplification of the conserved 16S rRNA gene sequence. The PCR mix reaction with a final volume of $50 \mu \mathrm{L}$ consisted of $50 \mathrm{ng}$ of DNA template, 10X Taq DNA polymerase reaction buffer $\left(10 \mathrm{mmol} \mathrm{L}^{-1}\right.$ of Tris$\mathrm{HCl} \mathrm{pH} 9$ and $50 \mathrm{mmol} \mathrm{L}^{-1}$ of $\mathrm{KCl}$ ), $1.5 \mathrm{mmol} \mathrm{L}^{-1} \mathrm{MgCl}_{2}$, $200 \mu \mathrm{mol} \mathrm{L}{ }^{-1}$ dNTP with equal concentrations of dATP, dTTP, dCTP and dGTP, 2 U of Taq DNA polymerase and 25 pmoL of each primer AMP-F [5'- GAG AGT TTG ATY CTG GCT CAG -3 '] and AMP-R [5'- AAG GAG GTG ATC CAR CCG CA - 3 '] (Wang et al., 1996). The amplification reaction was carried out in the PTC 100 thermocycler (MJ Research) of initial denaturation at $95{ }^{\circ} \mathrm{C}$ for $5 \mathrm{~min}$, followed by 34 cycles of denaturation at $94{ }^{\circ} \mathrm{C}$ for $15 \mathrm{sec}$, annealing at a temperature of $60{ }^{\circ} \mathrm{C}$ for $45 \mathrm{sec}$ with an extension at $72{ }^{\circ} \mathrm{C}$ for $2 \mathrm{~min}$, and a final extension at $72{ }^{\circ} \mathrm{C}$ for $30 \mathrm{~min}$. At the end of the reaction, the products were analyzed by electrophoresis in agarose gel $(1 \%)$.

For the identification and phylogenetic analysis, PCR products of each isolate were purified using the DNA purification kit and then sequenced. The sequences of these 74 strains were submitted to the Genbank database.

The phylogenetic tree with $16 \mathrm{~S}$ rRNA $(\sim 1300$ bp) was built using the Neighbor-Joining method. The bootstrap method with 1000 repetitions was used to evaluate the topology of the sequences (Felsenstein, 1985). The evolutionary distance was computed using the Tamura-3-parameter method and the phylogenetic analysis was carried out in the program MEGA 6 (Tamura et al., 2013).

\section{The functional capacity of the PGPR strains}

We selected 55 strains representing 10 Paspalum genotypes to assess the functional ability of the strains.

We used the National Botanical Research Institute's phosphate growth medium (NBRIP) agar culture medium containing $\mathrm{Ca}_{3}\left(\mathrm{PO}_{4}\right)_{2}$ to evaluate the capacity of phosphate to solubilize the isolates, according to Nautiyal (1999). The bacteria were previously cultured in a DYGS medium for $24 \mathrm{~h}$, and $10 \mu \mathrm{L}\left(\mathrm{OD}_{600}=0.9\right.$ 1.0) was placed onto the culture medium surface in the NBRIP plate, in triplicate. The P solubilization halo $(\mathrm{mm})$ was quantified by calculating the solubilization index (SI) according to Kumar and Narula (1999) after 7 and 14 days of incubation. G. diazotrophicus PAL5 was used as a reference strain for inorganic P solubilization.

Isolates were also characterized by the production of indole compounds, as described by Sarwar and Kremer (1995). Bacterial culture $(1 \mathrm{~mL})$, previously cultured for $24 \mathrm{~h}$ in DYGS medium, was inoculated into $5 \mathrm{~mL}$ of DYGS medium supplemented with L-tryptophan $\left(100 \mu \mathrm{g} \mathrm{mL}^{-1}\right)$ and incubated in the dark with shaking at $150 \mathrm{rpm}$ at $30^{\circ} \mathrm{C}$ for $48 \mathrm{~h}$. Aliquots of $1 \mathrm{~mL}$ were removed and centrifuged at $5000 \times \mathrm{g}$ for $15 \mathrm{~min}$. In a microplate 96-well, an aliquot of $150 \mu \mathrm{L}$ of supernatant was mixed with $100 \mu \mathrm{L}$ of the Salkowski reagent $(1 \mathrm{~mL}$ of $0.5 \mathrm{M} \mathrm{FeCl}_{3}$ in $49 \mathrm{ml}$ of $35 \%$ perchloric acid), which had been previously prepared. The quantification of indole compounds was evaluated by using a calibration curve prepared with serial dilutions of synthetic IAA standards (5-100 $\mu \mathrm{g}$ tryptophan $\left.\mathrm{mL}^{-1}\right)$. The results were expressed in $\mu \mathrm{g} \mathrm{mL} L^{-1}$ of IAA per unit of optical density. $A$. baldaniorum Sp245 was used as reference for indolic compound production.

Siderophore production was evaluated according to Tortora et al. (2011). The isolates had been previously grown in test tubes containing $5 \mathrm{~mL}$ of the bacterial growth media NFB, LGI, and LG (ironfree, supplemented with $0.1 \% \mathrm{NH}_{4} \mathrm{Cl}$ and without 
bromothymol blue) and incubated for $72 \mathrm{~h}$ at $30^{\circ} \mathrm{C}$ with constant stirring at $150 \mathrm{rpm}$. Then, four aliquots of 10 $\mu \mathrm{L}$ of the bacterial suspension $\left(\mathrm{OD}_{560}=0.2\right)$ were placed onto Petri dishes containing solid LG, NFB, and LGI media without bromothymol blue, supplemented with $0.1 \% \mathrm{NH}_{4} \mathrm{Cl}$ and Chromoazurol S (CAS) and incubated at $30{ }^{\circ} \mathrm{C}$ for 14 days. The production of siderophores was detected according to halo production. The strain ZAE94 Herbaspirillum seropedicaewas used as positive reference.

The functional information was used to calculate the Principal Component Analysis (PCA) and showed the similarity of the isolates in growth-promoting traits. The PCA was calculated with the correlation matrix since the variables were expressed in different units and presented as arrows in the PCA plot. All analyses were performed using PAST 4.3 program.

\section{Greenhouse experiments}

We selected three Paspalum genotypes based on forage features and seed availability to evaluate the best plant-bacteria interaction in greenhouse conditions. Three greenhouse experiments were carried out at the same time with the Paspalum genotypes $(P$. regnellii, $P$. atratum, and $P$. malacophylum) at Seropédica, Rio de Janeiro, Brazil. Three trains belonging to each genotype were selected based on functional characterization. The inoculation treatments consisted of strains: PR21 (Rhizobium sp.), PR23 (Bacillus sp.), PR8 (Acinetobacter sp.) for P. regnellii; PA121 (Bacillus sp.), PA122 (unknown genera) and PA123 (Bacillus sp.) for P. atratum cv. Pojuca genotype; PMA112 (Pseudomonas sp.), PMA115 (Bacillus sp.) and PMO18 (Bacillus sp.) for P. malacophyllum genotype. In addition to uninoculated and nitrogen (150 kg N ha-1) controls, strain Sp245 (A. baldaniorum) was used as a positive reference because it promotes growth in different grasses and on previous study in our laboratory. $\mathrm{N}$ was applied as ammonium sulfate and split into two doses at $20\left(50 \mathrm{~kg} \mathrm{~N} \mathrm{ha}^{-1}\right)$ and 32 days (100 kg N $\left.\mathrm{ha}^{-1}\right)$. The strains had been previously grown in a DYGS medium at $30{ }^{\circ} \mathrm{C}$, at $150 \mathrm{rpm}$ for $24 \mathrm{~h}$ followed by mixing $15 \mathrm{~mL}$ of the bacterial suspension in polypropylene bags containing $35 \mathrm{~g}$ of sterile peat. In the experiment, we used planosol soil with the following characteristics $\mathrm{pH}$ 5.84, Al $0.00 \mathrm{cmolc} \mathrm{dm}^{-3}$, Ca $1.50 \mathrm{cmolc} \mathrm{dm}^{-3}, \mathrm{H}+\mathrm{Al}$ 2.49 cmolc $\mathrm{dm}^{-3}, \mathrm{Mg} 0.75 \mathrm{mg} \mathrm{L}^{-1}, \mathrm{~K} 33.11 \mathrm{mg} \mathrm{L}^{-1}, \mathrm{P}$ $5.84 \%$, and $\mathrm{N} 0.06 \%$. Two fertilizations were carried out with nutrient solution (Franco and Döbereiner, 1967) at 29 and 50 DAP to restore the micronutrients and macronutrients, except for $\mathrm{N}$.

The experimental design was in randomized blocks with six replicates. Ten seeds were planted per $12 \mathrm{~kg}$ soil box. Seed inoculation was performed at a ratio of $10 \mathrm{~g}$ of peat $\mathrm{kg}$ per seed and sugar solution (10\%) was added at the proportion of $6 \mathrm{~mL} \mathrm{~kg}$ for better adhesion of the peat. Peat inoculants had approximately $10^{9}$ bacterial cells $\mathrm{g}^{-1}$.
The height of the plants was measured with a millimeter ruler (a representative main tiller was selected in each box at soil level measurement up to the young leaf ligule) and the number of tillers determined at 60 DAP as well as shoot dry matter accumulated at 38,68 and 98 DAP. The plant material was harvested on three occasions by cutting shoots at $10 \mathrm{~cm}$ soil height at 38 days and 68 DAP and at the end of the experiment (98 DAP), the roots were also harvested and evaluated.

Fresh shoot and root matter was dried at $65{ }^{\circ} \mathrm{C}$ for $48 \mathrm{~h}$ and then weighed. The shoot samples were ground in a mill and $\mathrm{N}$ content was analyzed according to the Kjedhal method. Crude protein in the shoots was determined by multiplying the $\mathrm{N}$ concentration by 6.25 .

The data from genotypes were analyzed independently. Software R version 3.3.2 and the analysis of variance (ANOVA) were used to test normality and homogeneity of the data. Tukey test was used $(p<0.05)$ to compare the means.

\section{Results and Discussion}

\section{Quantification of the culturable rhizobacterial population}

The number of PGPR ranged from not-detected to $10^{7}$ bacterial cells per gram of fresh matter among the 10 Paspalum genotypes. The highest bacterial values were observed in roots (semisolid LGI medium and LG agar plate medium) and in the rhizospheric soil (semisolid $\mathrm{NFb}$ medium). The greatest number of rhizobacteria was found in roots of $P$. notatum genotype (BGP 318); however, the largest number of bacterial isolates was detected in $P$. regnellii genotype (BGP 215) (Table 1). Ribeiro et al. (2020) observed similar results evaluating 20 genotypes of Brachiaria in semisolid NFb and LGI media, where a great bacterial population did not correlate with a larger number of isolates.

We successfully isolated 164 bacterial strains associated to the 10 Paspalum genotypes, mostly from roots $(54 \%)$, in contrast to the rhizospheric soil (46\%) (Table 1). We isolated 126 isolates from the LG agar plate medium, 17 from the semisolid $\mathrm{NFb}$ and 17 from the semisolid LGI media. However, only 130 isolates remained viable after storage in the appropriate medium. The PGPR population was also variable for many grass genotypes, including elephant grass (Videira et al., 2012), Brachiaria (Ribeiro et al., 2020), sugarcane (Reis Jr. et al., 2000), and Bahia grass (Dobereiner, 1966).

\section{Functional capacity of strains}

We analyzed 55 strains and, out of this total, 21 isolates showed siderophore production (SI), 14 strains solubilized inorganic phosphate (PP), and only nine strains showed the production of indole compounds (IC) (Table 2). Eleven strains failed to grow in CAS agar medium. The other strains grew in CAS agar medium; 
Table 1 - Most Probable Number (MPN) and Unit Forming Colony (UFC) of diazotrophic bacteria (DB) associated to roots and rhizosphere soil of 10 Paspalum genotypes kept at the Germoplasm Active Bank at Embrapa Pecuária Sudeste, São Carlos, São Paulo, Brazil.

\begin{tabular}{|c|c|c|c|c|c|c|c|c|c|c|c|c|c|c|}
\hline \multirow{3}{*}{ Paspalum species } & \multirow{3}{*}{ Genotypes } & \multicolumn{4}{|c|}{ NFb culture medium } & \multicolumn{4}{|c|}{ LGl culture medium } & \multicolumn{4}{|c|}{ LG culture medium } & \multirow{3}{*}{$\begin{array}{l}\text { Total number of } \\
\text { isolates in both } \\
\text { media/genotype }\end{array}$} \\
\hline & & \multicolumn{2}{|c|}{ fresh roots or per soil } & \multicolumn{2}{|c|}{$\begin{array}{c}\text { Number of } \\
\text { isolates }\end{array}$} & \multicolumn{4}{|c|}{$\begin{array}{l}\log _{10} n^{\circ} \text { cells or UFC g Number of } \\
\text { fresh roots or per soil isolates }\end{array}$} & \multicolumn{4}{|c|}{$\begin{array}{l}\log _{10} n^{\circ} \text { cells or UFC g Number of } \\
\text { fresh roots or per soil isolates }\end{array}$} & \\
\hline & & $\mathrm{R}$ & RS & $\mathrm{R}$ & RS & $\mathrm{R}$ & RS & $\mathrm{R}$ & RS & $\mathrm{R}$ & RS & $\mathrm{R}$ & RS & \\
\hline P. notatum & BGP 318 & 3.48 & 3.40 & 0 & 1 & 8.04 & 3.04 & 0 & 2 & 8.49 & 6.63 & 7 & 4 & 14 \\
\hline P. notatum & BGP 155 & 3.40 & 3.18 & 1 & 2 & 2.60 & 2.85 & 3 & 2 & 7.68 & 7.82 & 6 & 4 & 18 \\
\hline P. modestum & BGP 032 & ${ }^{*}-$ & 2.60 & 5 & 2 & 8.40 & 2.95 & 0 & 0 & ${ }^{*}-$ & 7.11 & 0 & 10 & 17 \\
\hline$P$. regnelliii & BGP 215 & 3.44 & 4.25 & 2 & 3 & 4.60 & 3.73 & 4 & 0 & 7.61 & 7.18 & 33 & 13 & 55 \\
\hline$P$. guenoarum & BGP 011 & *- & ${ }^{*}$ & 0 & 0 & *- & 2.60 & 0 & 2 & 7.83 & 7.24 & 5 & 7 & 14 \\
\hline P. regnelliii & BGP 344 & 2.60 & 2.95 & 0 & 0 & ${ }^{*}$ & 4.40 & 0 & 0 & 8.28 & 7.56 & 2 & 4 & 6 \\
\hline P. virgatum & BGP 343 & ${ }^{*}$ & *- & 0 & 0 & 9.15 & 3.40 & 0 & 1 & 8.24 & 7.14 & 4 & 8 & 13 \\
\hline P. plicatulum & BGP 164 & *- & ${ }^{*}-$ & 0 & 0 & 5.40 & ${ }^{*}-$ & 1 & 0 & 8.29 & 7.32 & 3 & 2 & 6 \\
\hline P. malacophyllum & BGP 293 & 2.60 & 3.98 & 0 & 1 & 5.40 & 5.15 & 0 & 2 & 7.66 & 6.97 & 3 & 4 & 10 \\
\hline P. atratum & BGP 098 & 2.95 & 3.40 & 0 & 0 & 4.60 & 2.95 & 0 & 0 & 7.55 & 7.62 & 7 & 4 & 11 \\
\hline $\begin{array}{l}\text { Total number of isc } \\
\text { each niche/culture }\end{array}$ & $\begin{array}{l}\text { olates from } \\
\text { medium }\end{array}$ & & & 8 & 9 & & & 8 & 9 & & & 72 & 54 & 164 \\
\hline
\end{tabular}

Table 2 - Phosphate solubilization index (PP), Indolic compounds production (IC, $\mu \mathrm{g} I \mathrm{AA} \mathrm{mL} \mathrm{L}^{-1} \mathrm{OD}^{-1}$ ), and Siderophore production (SI) by rhizospheric soil (RS) and root bacterial strains isolated from ten Paspalum genotypes.

\begin{tabular}{|c|c|c|c|c|c|c|}
\hline Strains & Genera & Genotype & Origin* & PP & IC & SA \\
\hline Positive Control & & & - & 2.84 & 36.62 & + \\
\hline PN4 & Enterobacter & BRA 25020 & $\mathrm{R}$ & $\mathrm{Nd}$ & 16.83 & $\mathrm{Nd}$ \\
\hline PN10 & Enterobacter & BRA 25020 & $\mathrm{R}$ & $\mathrm{Nd}$ & 9.41 & $\mathrm{Nd}$ \\
\hline PN11 & Bacillus & BRA 25020 & $\mathrm{R}$ & 1.11 & $\mathrm{Nd}$ & $\mathrm{Nd}$ \\
\hline PN13 & Rhizobium & BRA 12254 & $\mathrm{R}$ & $\mathrm{Nd}$ & $\mathrm{Nd}$ & + \\
\hline PN15 & Bacillus & BRA 12254 & $\mathrm{R}$ & $\mathrm{Nd}$ & $\mathrm{Nd}$ & + \\
\hline PN18 & Bacillus & BRA 12254 & RS & 1.45 & $\mathrm{Nd}$ & $\mathrm{Nd}$ \\
\hline PN21 & Bacillus & BRA 12254 & RS & $\mathrm{Nd}$ & $\mathrm{Nd}$ & + \\
\hline PM029 & Rhizobium & BRA 6491 & RS & 2.27 & $\mathrm{Nd}$ & $\mathrm{Nd}$ \\
\hline PR4 & Bacillus & BRA 19186 & $\mathrm{R}$ & $\mathrm{Nd}$ & $\mathrm{Nd}$ & + \\
\hline PR6 & Bacillus & BRA 6491 & RS & $\mathrm{Nd}$ & $\mathrm{Nd}$ & + \\
\hline PR8 & Acinetobacter & BRA 19186 & $\mathrm{R}$ & 2.11 & 17.78 & + \\
\hline PR19 & Bacillus & BRA 19186 & RS & 1.75 & $\mathrm{Nd}$ & + \\
\hline PR21 & Rhizobium & BRA 19186 & RS & $\mathrm{Nd}$ & 22.86 & + \\
\hline PR22 & Unknown & BRA 19186 & $\mathrm{R}$ & 2.36 & 20.27 & + \\
\hline PGU79 & Rhizobium & BRA 3824 & $\mathrm{R}$ & $\mathrm{Nd}$ & $\mathrm{Nd}$ & + \\
\hline PS88 & Unknown & BRA 12424 & RS & $\mathrm{Nd}$ & $\mathrm{Nd}$ & + \\
\hline PGL96 & Pseudomonas & BRA 11401 & $\mathrm{R}$ & $\mathrm{Nd}$ & 13.60 & + \\
\hline PGL101 & Bacillus & BRA 11401 & RS & 2.24 & 9.26 & $\mathrm{Nd}$ \\
\hline PP105 & Bacillus & BRA 12700 & RS & $\mathrm{Nd}$ & $\mathrm{Nd}$ & + \\
\hline PA118 & Burkholderia & BRA 9610 & $\mathrm{R}$ & 1.05 & 2.79 & + \\
\hline PA121 & Bacillus & BRA 9610 & $\mathrm{R}$ & 2.15 & $\mathrm{Nd}$ & $\mathrm{Nd}$ \\
\hline PA123 & Bacillus & BRA 9610 & RS & $\mathrm{Nd}$ & $\mathrm{Nd}$ & + \\
\hline PM01 & Bacillus & BRA 6491 & $\mathrm{R}$ & $\mathrm{Nd}$ & $\mathrm{Nd}$ & + \\
\hline PM031 & Bacillus & BRA 6491 & RS & 1.78 & 22.9 & + \\
\hline PNN4 & Bacillus & BRA 12254 & RS & 1.73 & $\mathrm{Nd}$ & + \\
\hline PR23 & Bacillus & BRA 19186 & RS & 1.51 & $\mathrm{Nd}$ & + \\
\hline PM018 & Bacillus & BRA 6491 & RS & $\mathrm{Nd}$ & $\mathrm{Nd}$ & + \\
\hline PNL4 & Unknown & BRA 12254 & $\mathrm{R}$ & 1.12 & $\mathrm{Nd}$ & $\mathrm{Nd}$ \\
\hline PNL13 & Unknown & BRA 12254 & RS & 1.67 & $\mathrm{Nd}$ & $\mathrm{Nd}$ \\
\hline PNL14 & Bacillus & BRA 12254 & $\mathrm{R}$ & $\mathrm{Nd}$ & $\mathrm{Nd}$ & + \\
\hline
\end{tabular}

nevertheless, they did not produce siderophores (no halo formation) until the $14^{\text {th }}$ day of incubation. The best siderophore strain producers were PA123, PN21, PA118, PNL14, PMO31, PNN4, and PR23, most of which were isolated from rhizospheric soil and belonged to the genus Bacillus (Table 2).

The siderophore production was the main activity detected among the bacterial isolates from Paspalum genotypes. This trait could be an advantage against ineffective indigenous bacteria in rhizosphere. Siderophores are organic molecules with low molecular weight synthesized by microorganisms considered an alternative to chemical pesticides and biocontrol agents in the agriculture (Sasirekha and Srividya, 2016).

Bacterial strains isolated from roots (7) and rhizospheric soil (2) of Paspalum genotypes BGP 098, BGP 343, BGP 318, BGP 343, BGP 215, and BGP 032 produced IC ranged from 2.79 to $36.62 \mu \mathrm{g}$ of IAA $\mathrm{mL}^{-1} \mathrm{OD}^{-1}$, all genotypes are closely related to genera Paraburkholderia, Bacillus, Enterobacter, Pseudomonas, and Acinetobacter. The production of indolic compounds by PGPR agrees with reports of other authors (Cássan et al., 2013; Chaves et al., 2015; Ribeiro et al., 2020), who found values of indole production in vitro ranging from 10 to 50 IAA $\mu \mathrm{g} \mathrm{mL} \mathrm{m}^{-1} \mathrm{OD}^{-1}$ for PGPR isolated from sugarcane and Brachiaria. Exogenous indole compounds are known to play a role in root development (Costacurta and Vanderleyden, 1995; Patten and Glick, 1996) and act during plant drought stress (Nabti et al., 2010).

Although $\mathrm{P}$ is present from 95 to $99 \%$ in soils, it is unavailable to the plants, due to its fixation on soil mineral particles or precipitation by ions $\mathrm{Al}^{+3}$ and $\mathrm{Fe}^{+3}$. Phosphate-solubilizing rhizobacteria increase solubilization of insoluble $\mathrm{P}$ compounds by lowering the $\mathrm{pH}$ through microbial production of organic acids (Anand et al., 2016; Sharma et al., 2013; Vassileva et al., 2000; $\mathrm{Wu}, 2005)$. 
According to Madhaiyan et al. (2004), the P solubilization index (SI) can be classified as high (SI $>3)$, medium $(2<$ SI $<3)$, and low (SI $<2)$. The SI ranged from 1.11 to 2.36 , which was considered medium-to-low and lower than that observed for $G$. diazotrophicus strain PAL5 (reference strain) with an SI from 2.84 to 3.07 .

Pseudomonas and Bacillus are considered the most frequent phosphate solubilizing bacteria; however, the occurrence of other P solubilizing species has also been reported (Sharma et al., 2013).

The strains differ in terms of their functional abilities and most were capable of producing siderophore, while Bacillus sp. strain PGL101 and Acinetobacter sp. strain PR8 produced indolic compounds and solubilized phosphate. PMO31 (unknown genus), Pseudomonas sp. strain PGL96 and Rhizobium sp. strain PR21produced indolic compounds and siderophores, while Bacillus sp. strains PR23 and PR19 solubilized P and produced siderophores. The siderophore production was the main activity detected among the bacterial isolates from Paspalum genotypes, which could be an advantage against ineffective indigenous bacteria in rhizosphere. Siderophores are organic molecules with low molecular weight synthesized by microorganisms considered as an alternative to chemical pesticides and biocontrol agents in the agriculture (Sasirekha and Srividya, 2016).

Only strains PA118 (Paraburkholderia), isolated from roots of $P$. atratum cv. Pojuca (BGP 098), and PR22 (unknown genus) from roots of P. regnellii (BGP 215), performed better and showed capacity to solubilize phosphate (SI) and produce indolic compounds (IC) and siderophore (SA).

The PCA explained $69 \%$ of data variability in the first two components (Figure 1). The first component explained $41 \%$ of the variation and could be represented for SA mainly in rhizospheric soil. The second component explained $27 \%$ of the variation and could be represented for SI and followed by IC. These in vitro results allowed to select strains with multifunctional abilities, pointing to possibilities to assess PGPR inoculation in Paspalum forage grasses.

\section{Molecular characterization}

The taxonomical analysis based on $16 \mathrm{~S}$ rRNA sequences of 74 strains isolated from the 10 Paspalum genotypes showed that the strains belonged to 11 genera of the Proteobacteria classes (alpha, beta and gamma) and Firmicutes. Most isolates belonged to the genus Bacillus $(N=55)$, Rhizobium $(N=7)$, Paraburkholderia $(N=2)$, Enterobacter $(N=2)$, Cupriavidus $(N=1)$, Pseudomonas $(N=2)$, Dyadobacter $(N=1)$, Acinetobacter $(N=2)$, Microbacterium $(N=1)$, and Azospirillum $(N=1)$ (Figures $2 \mathrm{~A}$ and 2B). Interestingly, the genus Bacillus was found in roots and rhizospheric soil of all Paspalum genotypes, while Rhizobium was found mainly in roots of Paspalum genotypes (BGP 293, BGP 155, BGP 215, BGP 032, and BGP 011), except for $P$. atratum BGP 098 genotype, which was found in rhizospheric soil. The $P$. notatum (BGP 318

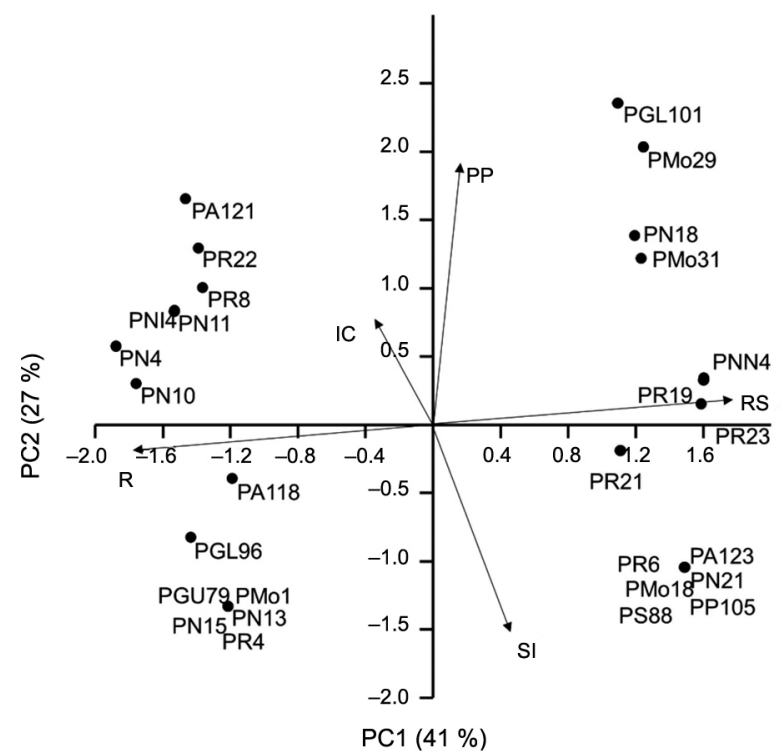

Figure 1 - Principal component analysis (PCA) of functional characterization by 28 bacterial strains from Paspalum genotypes. $\mathrm{IC}=$ Indolic compound production, $\mathrm{PP}=$ Phosphate solubilization index, $\mathrm{SI}=$ Siderophore production, $\mathrm{RS}=$ rhizosferic soil and $\mathrm{R}=$ fresh roots.

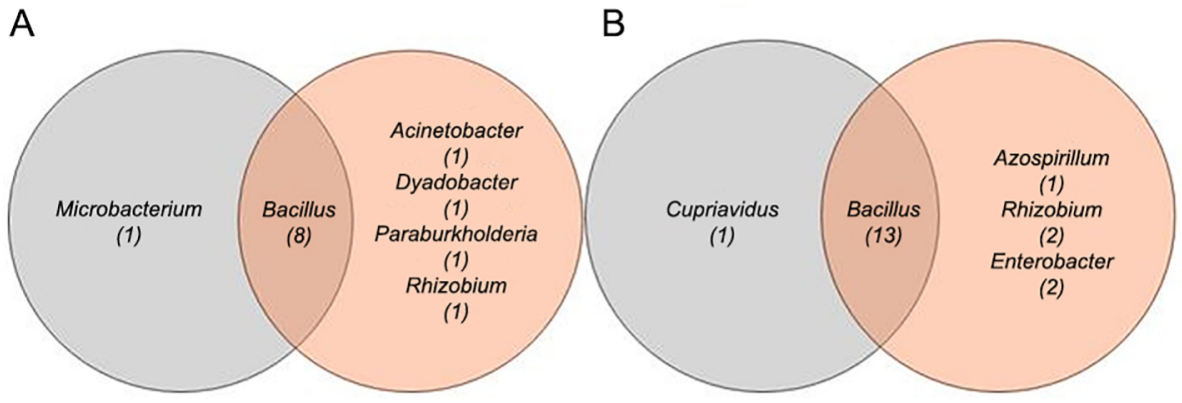

Figure 2 - Venn diagram demonstrating the number of Rhizobacteria genera isolated from rhizospheric soil (in blue) and root samples (in pink) in (A) $P$. regnellii and (B) $P$. notatum. 
and BGP 155) and P. regnellii (BGP 215 and BGP 344) were colonized by different bacterial species, mainly in roots (Figure 3). In contrast, only strain 3LI was isolated from the soil of $P$. notatum (PGP 318) in the semi-selective $\mathrm{NFb}$ medium and was similar to Azospirillum sp.

Döbereiner (1966) detected the presence of Azorhizophilus paspali (syn. Azotobacter paspali) in $98 \%$ and $66 \%$ of samples of $P$. notatum cv. batatais and $P$. plicatum, respectively, but not from the other Paspalum genotypes. Surprisingly, we were not able to isolate this genus from any of the Paspalum genotypes kept in the Paspalum GAB; nevertheless, we were able to isolate the $A$. paspali strain PN22 of P. notatum cv. Batatais grown in Seropédica, Rio de Janeiro, Brazil (unpublished data).

Most of our isolates belonged to the Bacillus genus, although many other new genera were also found, which are associated to the Paspalum genotypes. The genus Bacillus represents $95 \%$ of Gram-positive bacterial species found in the soil (Goswami et al., 2016). It was also the most representative group in our study for Paspalum plants. Beule et al. (2019), however, studied bacterial soil communities and cultivar-dependence in pastureland in northwestern Florida (USA) and found Candidatus udaeobacter, Bradyrhizobium spp., and Candidatus solibacter as the most abundant genera across Paspalum cultivars.

Genera Rhizobium, Paraburkholderia, Azospirillum, Enterobacter, Cupriavidus, Pseudomonas, Microbacterium were associated to different grasses (Baldani and Baldani, 2005; Prabha et al., 2019; Ribeiro et al., 2020), while Dyadobacter and Acinetobacter were isolated from wheat rhizosphere and stems of maize and iceberg lettuce, respectively (Chelius and Triplett, 2000; Du et al., 2016; Rooney et al., 2016).

There is no clear explanation why Azorhizophilus. (syn Azotobacter) paspali was not isolated or more isolates belonged to Azospirillum spp. or Nitrospirillum amazonense of the 10 Paspalum genotypes. One possibility could be the $\mathrm{N}$ level (150 $\mathrm{kg} \mathrm{N} \mathrm{ha}^{-1}$ ) applied every year to ensure plant nutrition in GAB. It is known that $\mathrm{N}$ interferes with the bacterial population associated to grasses e.g. sugarcane, rye-grass, maize and Bahia grass (Beule et al., 2019; Castanheira et al., 2014; Souza et al., 2016; Marques et al., 2017; Van Deynze et al., 2018). Another possibility could be the genotype specificity observed by Döbereiner (1966), although no specific chemo-attractant compound was detected associated to P.notatum cv. Batatais in other studies (Döbereiner et al., 1972; Machado and Döbereiner, 1969) that could be associated to the bacterial specificity observed by Döbereiner (1966).

PGPR inoculation effects on $P$. regnellii (BGP 215), $P$. atratum (BGP 098), and P. malacophylum (BGP 293)

Plants of $P$. regnellii inoculated with Azospirillum baldaniorum strain Sp245 performed better than other inoculated plants for most variables in the sum of the

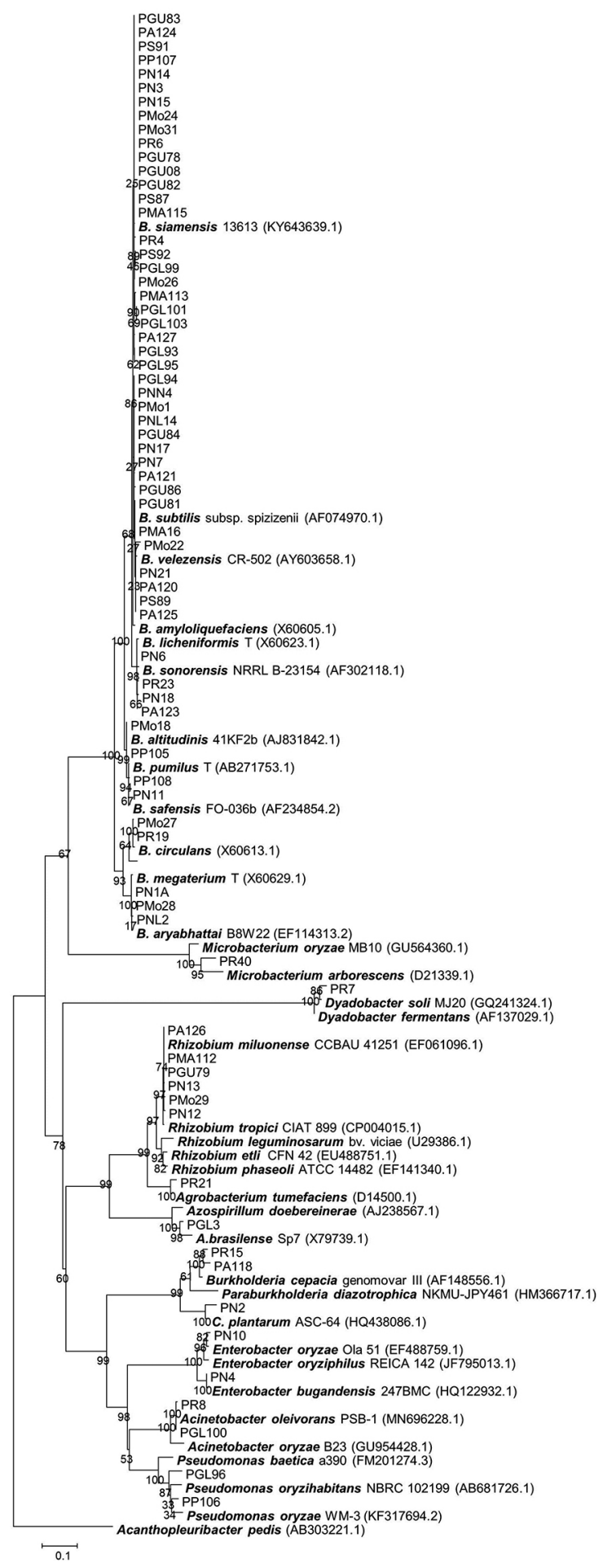

Figure 3 - Phylogenetic tree based on 16S rRNA gene sequences ( $1450 \mathrm{bp}$ ), including the bacterial type strain deposited in the NCBI database. Phylogeny was based on clustering of sequences according to the Neighbor-joining algorithm and Kimura model using the MEGA6.1 program. Numbers in the branches indicate the percentage of 1000 sub-samples (bootstrap). The scale represents the number of mutations per nucleotide position. The Acanthopleuribacter pedis $16 \mathrm{~S}$ rRNA gene sequence was used for tree rooting. 
three cuttings (Table 3). The $A$. baldoniorum species was recently created and included the old $A$. brasilense strain Sp245 and two other strains (Vi22 and BR12001) (Ferreira et al., 2020). Inoculation of strain Sp245 promoted a Shoot Dry Matter (SDM) yield 53 \% higher than the control treatment, while total $\mathrm{N}$ in plants inoculated with strain PR23 was $26 \%$ higher than the control, but $36 \%$ lower than strain Sp245 and $\mathrm{N}\left(120 \mathrm{~kg} \mathrm{~N} \mathrm{ha}^{-1}\right)$ treatments. There was an increase of $58 \%$ in total $\mathrm{N}$ of $P$. regnellii shoots compared to the treatment without inoculation with strain Sp245. Interestingly, P. regnellii plants inoculated with Sp245 presented early seed emergence (seven days after planting) and accumulated $24 \%$ more $\mathrm{N}$ than the treatment with $\mathrm{N}$ fertilizer $(120 \mathrm{~kg}$ $\mathrm{N} \mathrm{ha}^{-1}$ ) in the first harvest (Figure 4), also greater plant height and number of tillers at 60 DAP. Inoculation of strain PR21 was similar to Sp245 for root dry matter (RDM), while inoculation of strain PR23 did not differ from the control (Table 3).

The response of $P$. atratum cv. Pojuca to strain inoculation showed that this genotype is highly responsive to $\mathrm{N}$ fertilization $\left(120 \mathrm{~kg} \mathrm{~N} \mathrm{ha}^{-1}\right)$ in the sum of the three cuttings (Table 3). Nevertheless, promising results were observed due to the inoculation of strains PA121 and PA123 regarding the number of tillers at 60 DAP (Table 3) and in the first SDM cutting (Figure 5), respectively. However, negative or null effects were demonstrated with inoculation of strain Sp245 for most variables.

Inoculation of strain Sp245 also promoted a positive effect on $P$. malacophylum with outstanding results as a shoot growth-promoting bacterium, while strains PMA112 and PMO18 appear as root growthpromoting rhizobacteria (Table 3). The gain in SDM was higher in the second and third harvests with strain inoculation of Sp245; however, an increase in the shoot $\mathrm{N}$ content was not verified (Figure 6). Total crude protein was higher only in the $\mathrm{N}$ fertilizer treatment (Table 3).

The analyses of responses of the three Paspalum genotypes to inoculation with PGPR strains suggest a genotype effect associated to each inoculated strain. The best response was observed in $P$. regnellii inoculated with strain Sp245, which showed high shoot biomass and total $\mathrm{N}$ accumulated in plant tissues. Our initial hypothesis that PGPR strains isolated from the host plant, that is, "host genotype specificity", could be more efficient when inoculated in their host genotype was not confirmed. The host genotype strains showed reduced efficiency in all three Paspalum genotypes. Obviously, a greater number of host genotype strains need to be tested mainly in association with $P$. regnellii, which showed response to all agronomic traits. Many of these

Table 3 - Inoculation effect of PGPR strains on height (H), number of tillers (T), total shoot dry matter (SDM), total nitrogen uptake (N), total crude protein (CP), and root dry matter (RDM) of $P$. regnellii, $P$. atratum cv. Pojuca and $P$. malacophyllum.

\begin{tabular}{|c|c|c|c|c|c|c|}
\hline & \multicolumn{6}{|c|}{ P. regnelliii } \\
\hline & $\mathrm{H}$ & $\mathrm{T}$ & SDM & $\mathrm{N}$ & $\mathrm{CP}$ & RDM \\
\hline & $\mathrm{cm}$ & units & g per plant & \multicolumn{2}{|c|}{ mg per plant } & g per plant \\
\hline Control & $44.23 c$ & $4.00 \mathrm{c}$ & $2.74 \mathrm{c}$ & $37.93 \mathrm{~cd}$ & $237.08 \mathrm{c}$ & $2.52 b$ \\
\hline Rhizobium spp. PR21 & $41.02 \mathrm{c}$ & $4.00 \mathrm{c}$ & $2.66 \mathrm{c}$ & $35.55 \mathrm{~d}$ & $222.21 \mathrm{c}$ & $3.31 \mathrm{ab}$ \\
\hline Bacillus spp. PR23 & $43.93 c$ & $5.83 b$ & $3.09 \mathrm{bc}$ & $47.71 \mathrm{c}$ & $298.20 \mathrm{bc}$ & $2.44 \mathrm{~b}$ \\
\hline Acinetobacter spp. PR8 & $44.75 \mathrm{c}$ & $4.67 \mathrm{c}$ & $2.58 \mathrm{c}$ & $36.26 \mathrm{~d}$ & $226.64 \mathrm{c}$ & $2.56 \mathrm{~b}$ \\
\hline $150 \mathrm{~kg}$ de $\mathrm{N}$ & $49.20 b$ & $5.00 \mathrm{~b}$ & $8.27 \mathrm{a}$ & $132.35 \mathrm{a}$ & $827.22 \mathrm{a}$ & $5.24 \mathrm{a}$ \\
\hline Sp245 & $55.75 a$ & $7.67 \mathrm{a}$ & $4.19 b$ & $60.07 \mathrm{~b}$ & $375.43 b$ & $3.11 \mathrm{ab}$ \\
\hline \multirow[t]{3}{*}{ CV (\%) } & 11.11 & 13.37 & 32.93 & 36.80 & 36.80 & 28.84 \\
\hline & \multicolumn{6}{|c|}{ P. atratum cv. Pojuca } \\
\hline & $\mathrm{H}$ & $\mathrm{T}$ & SDM & $\mathrm{N}$ & $\mathrm{CP}$ & RDM \\
\hline Control & 45.72 & $4.33 b$ & $3.38 b$ & $42.23 b$ & 263.94 b & $2.38 b$ \\
\hline Unknown spp. PA122 & 45.48 & $4.17 b$ & $3.10 \mathrm{~b}$ & $37.59 \mathrm{~b}$ & $234.97 \mathrm{bc}$ & $2.77 \mathrm{~b}$ \\
\hline Bacillus spp. PA121 & 48.42 & $5.50 \mathrm{a}$ & $3.16 b$ & $39.34 b$ & 245.87 b & $2.82 b$ \\
\hline Bacillus PA123 & 47.22 & $4.50 \mathrm{~b}$ & $3.05 b$ & $40.75 b$ & $254.71 b$ & $2.71 b$ \\
\hline 150 kg de $\mathrm{N}$ & 46.62 & $3.83 b$ & $6.22 \mathrm{a}$ & $88.84 \mathrm{a}$ & $555.27 \mathrm{a}$ & $5.05 \mathrm{a}$ \\
\hline Sp245 & 51.68 & $6.50 \mathrm{a}$ & $2.48 \mathrm{c}$ & $28.42 \mathrm{c}$ & $177.61 \mathrm{c}$ & $2.16 b$ \\
\hline \multirow[t]{3}{*}{ CV \% } & 8.35 & 23.18 & 11.37 & 11.54 & 11.54 & 26.06 \\
\hline & \multicolumn{6}{|c|}{ P. malacophyllum } \\
\hline & $\mathrm{H}$ & $\mathrm{T}$ & SDM & $\mathrm{N}$ & $\mathrm{CP}$ & RDM \\
\hline Control & $40.05 c$ & $4.50 b$ & $2.33 \mathrm{bc}$ & $32.44 \mathrm{bc}$ & $202.77 b$ & $0.59 \mathrm{~d}$ \\
\hline Pseudomonas spp. PMA112 & $36.79 \mathrm{c}$ & $4.83 b$ & $2.34 \mathrm{bc}$ & $33.30 \mathrm{bc}$ & $208.14 b$ & $2.77 \mathrm{a}$ \\
\hline Bacillus spp. PM018 & $36.73 \mathrm{c}$ & $4.67 b$ & $2.16 \mathrm{bc}$ & $32.17 \mathrm{bc}$ & $201.07 b$ & $1.56 \mathrm{~b}$ \\
\hline Bacillus spp. PMA115 & $39.33 \mathrm{c}$ & $4.83 b$ & $2.06 \mathrm{c}$ & $29.25 \mathrm{c}$ & $182.85 b$ & $0.90 \mathrm{~cd}$ \\
\hline $150 \mathrm{~kg} \mathrm{~N}$ & $45.02 \mathrm{~b}$ & $5.83 b$ & $5.78 \mathrm{a}$ & $81.81 \mathrm{a}$ & 511.29 a & $1.01 \mathrm{C}$ \\
\hline Sp245 & $53.28 \mathrm{a}$ & $11.17 \mathrm{a}$ & $2.67 \mathrm{~b}$ & $34.89 \mathrm{~b}$ & $218.62 \mathrm{~b}$ & $0.36 \mathrm{e}$ \\
\hline CV \% & 10.67 & 25.87 & 14.94 & 15.68 & 15.68 & 23.98 \\
\hline
\end{tabular}

Values of three harvests and means of six replicates. The same letters do not differ by the Tukey test ( $p \leq 5 \%)$. 


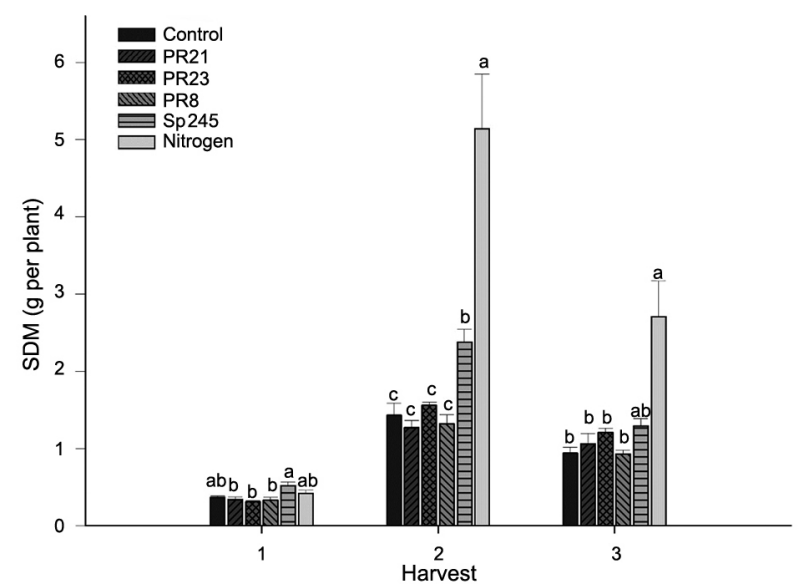

Figure 4 - Shoot dry matter (SDM) accumulation at 38 days after planting (1), 68 days after planting (2) and (3) 98 days after planting in $P$. regnellii plants inoculated with PGPR. Error bars represent the mean standard error $(n=6)$. The same letters do not differ by the Tukey test ( $p \leq 5 \%$ ).

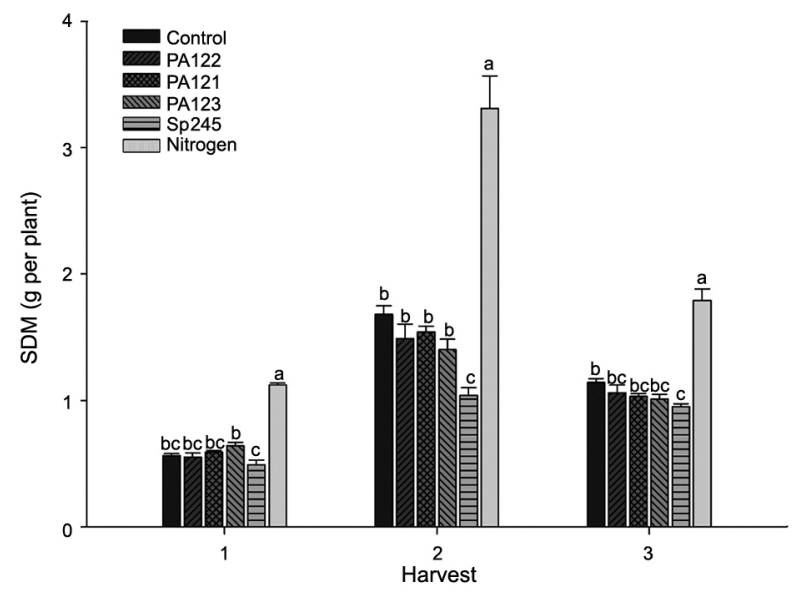

Figure $\mathbf{5}$ - Shoot dry matter (SDM) accumulation of $P$. atratum $\mathrm{cv}$. Pojuca plants collected at 38 days after planting (1), 68 days after planting (2) and (3) 98 days after planting and inoculated with PGPR. Error bars represent the mean standard error $(n=6)$. The same letters do not differ by the Tukey test $(p \leq 5 \%)$.

strains have not yet been tested in Paspalum genotypes and therefore should be explored in more detail.

The beneficial effect of $A$. brasilense on growth of different cereals or even different species may be associated to motility and the chemotaxis ability in different types of root exudates (Bashan and DeBashan, 2015; Reinhold et al., 1985). A. baldaniorum (old $A$. brasilense) strain Sp245 normally establishes endophytically in plants, such as wheat (Schloter et al., 1994), promoting plant growth through the production of phytohormones, such as IAA, cytokine, gibberellin, and bacterial volatiles (Sharifi et al., 2018). These chemical substances enhance root development that, in turn, increase nutrient uptake and water use efficiency therefore promoting biomass gain (Cassán et al., 2013). These effects may have happened with Sp245 strain in

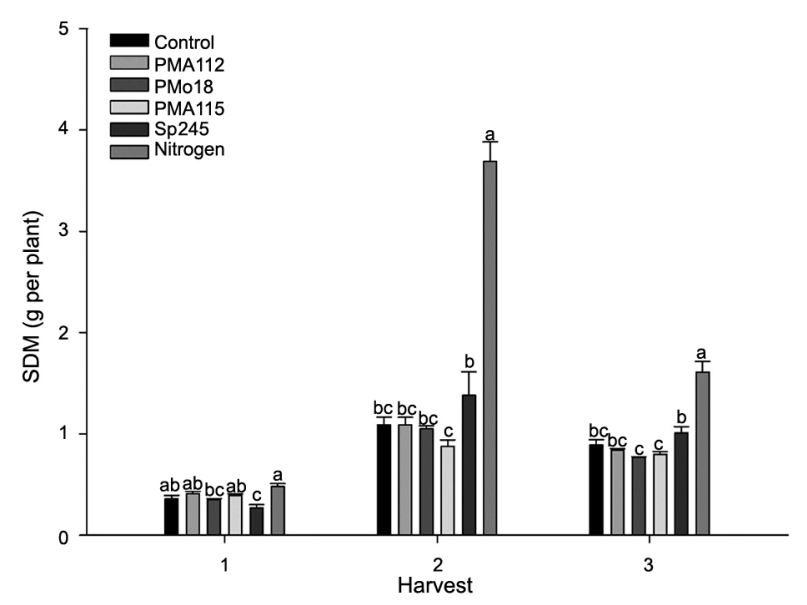

Figure 6 - Shoot dry matter (SDM) accumulation of $P$. malacophylum plants at 38 days after planting (1), 68 days after planting (2) and (3) 98 days after planting and inoculated with PGPR. Error bars represent the mean standard error $(n=6)$. The same letters do not differ by the Tukey test ( $p \leq 5 \%$ ).

association with $P$. regnellii although it does not explain the partial response or absence of response to other Paspalum genotypes ( $P$. malacophylum and P. atratum cv. Pojuca). This strain increased mainly the shoot biomass of $P$. malacophylum, while its inoculation had a deleterious effect on all agronomic variables evaluated in P. atratum cv. Pojuca. Lobo et al. (2019) found a similar result during the inoculation of Bacillus subtilis strain BS-263 in maize plants, although the strain also produced indolic compounds in vitro.

The plant immune system may be the cause of the deleterious effect of inoculation caused by some bacterial strains, which may not recognize the bacteria as beneficial thus making the plant-bacterial interaction incompatible (Teixeira et al., 2019). While P. regnellii inoculated with strain Sp245 showed increased biomass accumulation of the whole plant, promoting traits, inoculation with the host strains Pseudomonas sp. strain PMA112 and Bacillus sp. strain PMO18 promoted only root growth in Paspalum malacophylum.

The PGPR association promote favorable environmental conditions for the establishment of the plant, that is, the $\mathrm{pH}$, humidity, and supply of photo assimilates in contrast to the $\mathrm{N}$ fixed by the microorganisms (Reis et al., 2018). Several studies indicate that the efficiency of associative diazotrophs depends on plant genotype and age, which generate various responses that must be previously tested to certify the inoculation technique. The strain/species also modulates the communication between the pre-existing microbial community and the strain introduced as an inoculant (Hungria et al., 2016; Ikeda et al., 2020; Reis et al., 2018).

In conclusion, our results showed a great diversity of PGPR associated to Paspalum genotypes and revealed that the plant response to bacterial inoculation has no relationship with the host Paspalum genotypes. 


\section{Authors' Contributions}

Conceptualization: Baldani, J.I.; Amaral, M.B. Data acquisition: Mata, F.P.; Ribeiro, T.; Amaral, M.B.; Alves, G.C.; Coelho, M.R. Data analysis: Coelho, M.R.; Amaral, M.B.; Ribeiro, T.; Alves, G.C. Design of methodology: Baldani, V.L.D.; Baldani, J.I. Writing and editing: Baldani, J.I.; Baldani, V.L.D.; Amaral, M.B.

\section{Acknowledgments}

We thank the Brazilian National Council for Scientific and Technological Development (CNPq) for granting fellowships to the first author and J.I.B. (process $\mathrm{n}^{\circ}$ 306011/2017-4). This work was financially supported by the Brazilian Agricultural Research Corporation (project Embrapa MP2 ${ }^{\circ}$ 12.13.08.004.00.03) and the Coordination for the Improvement of Higher Level Personnel (CAPES) - Finance Code 001.

\section{References}

Anand, K.; Kumari, B.; Mallick, M.A. 2016. Phosphate solubilizing microbes: an effective and alternative approach as biofertilizers. International Journal of Pharmacy and Farmaceutical Sciences 8: $37-40$.

Antunes, T.C.; Ballarini, A.E.; Van Der Sand, S. 2019. Temporal variation of bacterial population and response to physical and chemical parameters along a petrochemical industry wastewater treatment plant. Anais da Academia Brasileira de Ciências 91: e20180394.

Backer, R.; Rokem, J.S.; Ilangumaran, G.; Lamont, J.; Praslickova, D.; Ricci, E.; Subramanian, S.; Smith, D.L. 2018. Plant growthpromoting rhizobacteria: context, mechanisms of action, and roadmap to commercialization of biostimulants for sustainable agriculture. Frontiers in Plant Science 9: 1473.

Baldani, J.I.; Baldani, V.L.D. 2005. History on the biological nitrogen fixation research in graminaceous plants: special emphasis on the Brazilian experience. Anais da Academia Brasileira de Ciências 77: 549-579.

Baldani, J.I.; Reis, V.M.; Videira, S.S.; Boddey, L.H.; Baldani, V.L.D. 2014. The art of isolating nitrogen-fixing bacteria from non-leguminous plants using $\mathrm{N}$-free semi-solid media: a practical guide for microbiologists. Plant and Soil 384: 413431.

Bashan, Y.; De-Bashan, L.E. 2015. Inoculant preparation and formulations for azospirillum spp. p. 469-485. In: Cassán, F.D.; Okon, Y.; Creus, C., eds. Handbook for Azospirillum. Technical issues and protocols. Springer, Basel, Switzerland.

Beule, L.; Chen, K.; Hsu, C.; Mackowiak, C.; Dubeux Jr., J.C.B.; Blount, A.; Liao, H. 2019. Soil bacterial and fungal communities of six bahiagrass cultivars. PeerJ Journal of Life and Environmental Sciences 7: e7014.

Cassán, F.; Vanderleyden, J.; Spaepen, S. 2013. Physiological and agronomical aspects of phytohormone production by model plant bacteria-promoting rhizobacteria (PGPR) belonging to the genus Azospirillum. Journal of Plant Growth Regulation 33: 44-59.
Castanheira, N.; Dourado, A.C.; Alves, P.I.; Cortés-Pallero, A.M.; Delgado-Rodríguez, A.I.; Prazeres, A.; Borges, N.; Sánchez, C.; Crespo, M.T.B.; Fareleira, P. 2014. Annual ryegrassassociated bacteria with potential for plant growth promotion. Microbiology Research 169: 768-779.

Chaves, V.A.; Santos, S.G.; Shultz, N.; Pereira, W.; Sousa, J.S.; Monteiro, R.C.; Reis, V.M. 2015. Initial development of two sugarcane varieties inoculated with diazotrophic bacteria. Revista Brasileira de Ciência do Solo 39: 1595-1602 (in Portuguese, with abstract in English).

Chelius, M.K.; Triplett, E.W. 2000. Dyadobacter fermentans gen. nov., sp. nov., a novel gram-negative bacterium isolated from surface-sterilized Zea mays stems. International Journal of Systematic and Evolutionary Microbiology 50: 751-758.

Costacurta, A.; Vanderleyden, J. 1995. Synthesis of phytohormones by plant-associated bacteria. Critical Reviews in Microbiology 21: 1-18.

Döbereiner, J. 1966. Azotobacter paspali sp. n., a nitrogen-fixing bacteria in the Paspalum rhizosphere. Pesquisa Agropecuária Brasileira 1: 357-365 (in Portuguese, with abstract in English).

Döbereiner, J.; Day, J.M.; Dart, P.J. 1972. Nitrogenase activity and oxygen sensitivity of the Paspalum notatum-Azotobacter paspali association. Microbiology 71: 103-116.

Du, J.; Singh, H.; Yu, H.; Jin, F.X.; Yi, T.H. 2016. Acinetobacter plantarum sp. nov. isolated from wheat seedlings plant. Archives of Microbiology 198: 393-398.

Felsenstein, J. 1985. Phylogenies and the comparative method. The American Naturalist 125: 1-15.

Ferreira, N.S.; Sant'Anna, F.H.; Reis, V.M.; Ambrosini, A.; Volpiano, C.G.; Rothballer, M.; Schwab, S.; Baura, V.A.; Balsanelli, E.; Pedrosa, F.O.; Passaglia, L.M.P.; Souza, E.M.; Hartmann, A.; Cassan, F.; Zilli, J.E. 2020. Genome-based reclassification of Azospirillum brasilense Sp245 as the type strain of Azospirillum baldaniorum sp. nov. International Journal of Systematic and Evolutionary Microbiology. https:// doi.org/10.1099/ijsem.0.004517

Franco, A.A.; Döbereiner, J. 1967. Host specificity in RhizobiumBean symbiosis and influence of different nutrients. Pesquisa Agropecuária Brasileira 2: 467-474 (in Portuguese, with abstract in English).

Goswami, D.; Thakker, J.N.; Dhandhukia, P.C.; Tejada, M.M. 2016. Portraying mechanics of plant growth promoting rhizobacteria (PGPR): a review. Cogent Food Agriculture 1: 127-500.

Hungria, M.; Nogueira, M.A.; Araújo, R.S. 2016. Inoculation of Brachiaria spp. with the plant growth-friendly component in the reclamation of degraded pastures in the tropics. Agriculture, Ecosystems and Environment 221: 125-131.

Ikeda, A.C.; Savi, D.C.; Hungria, M.; Kava, V.; Glienke, C.; GalliTerasawa, L.V. 2020. Bioprospecting of elite plant growthpromoting bacteria for the maize crop. Acta Scientiarum Agronomy 42: e44364.

Kumar, V.; Narula, N. 1999. Solubilization of inorganic phosphates and growth emergent of wheat as affected by Azotobacter chrococum mutants. Biology and Fertility of Soils 28: 301-305.

Lobo, L.L.B.; Santos, R.M.; Rigobelo, E.C. 2019. Promotion of maize growth using endophytic bacteria under greenhouse and field conditions. Australian Journal of Crop Science 13: 20672074. 
Machado, W.C.; Döbereiner, J. 1969. Complementary studies about physiology of Azotobacter paspali and its dependence to plant (Paspalum notatum). Pesquisa Agropecuária Brasileira 4: 53-58 (in Portuguese, with abstract in English).

Madhaiyan, M.; Saravanan, V.S.; Jovi, D.B.S.S.; Lee, H.; Thenmozhi, R.; Hari, K.; As, T. 2004. Occurrence of Gluconacetobacter diazotrophicus in tropical and subtropical plants of western Ghats, India. Microbiology Research 159: 233-243.

Manzur, M.E.; Grimoldi, A.A.; Striker, G.G. 2020. The forage grass Paspalum dilatatum tolerates partial but not complete submergence caused by either deep water or repeated defoliation. Crop and Pasture Science 71: 190-198.

Marques, A.C.R.; Oliveira, L.B.; Nicoloso, F.T.; Jacques, R.J.S.; Giacomini, S.J. Quadros, F.L.F. 2017. Biological nitrogen fixation in $\mathrm{C} 4$ grasses of different growth strategies of South America natural grasslands. Applied Soil Ecology 113: 54-62.

Marques, A.C.R.; Oliveira, L.B.D.; Brunetto, G.; Tavares, M.D.S.; Quadros, F.L.F.D.; Nicoloso, F.T. 2020. Interaction between growth strategies and phosphorus use efficiency in grasses from South America natural grasslands. Revista Ceres 67: 6269.

Nabti, E.; Sahnoune, M.; Ghoul, M.; Fischer, D.; Hofmann, A.; Rothballer, M. 2010. Restoration of growth of durum wheat (Triticum durum var. waha) under saline conditions due to inoculation with the rhizosphere bacterium Azospirillum brasilense $\mathrm{NH}$ and extracts of the marine alga Ulva lactuca. Journal of Plant Growth Regulation 29: 6-22.

Nautiyal, C.S. 1999. An efficient microbiological growth medium for screening phosphate solubilizing microorganisms. FEMS Microbiology Letters 170: 265-270.

Patten, C.L.; Glick, B.R. 1996. Bacterial biosynthesis of indole-3acetic acid. Canadian Journal Microbiology 42: 207-220.

Prabha, R.; Singh, D.P.; Gupta, S.; Gupta, V.K.; El-Enshasy, H.A.; Verma, M.K. 2019. Rhizosphere metagenomics of Paspalum scrobiculatum 1. (kodo millet) reveals rhizobiome multifunctionalities. Microorganisms 7: 608.

Reinhold, B.; Hurek, T.; Fendrik, I. 1985. Strain-specific chemotaxis of Azospirillum spp. Journal of Bacteriology 162: 190-195.

Reis, V.M.; Jesus, E.C.J.; Schwab, S.; Oliveira, A.L.M.; Olivares, F.; Baldani, V.L.D.; Baldani, J.I. 2018. Simbiotic and associative biological nitrogen fixation = Fixação biológica de nitrogênio simbiótico e associativa. p. 279-308. In: Fernandes, M.S.; Souza, S.R.; Santos, L.A., eds. Plant Mineral Nutrition = Nutrição mineral de plantas. Sociedade Brasileira de Ciência do Solo, Viçosa, MG, Brazil (in Portuguese).

Reis Junior, F.B.; Reis, V.M.; Urquiaga, S.; Döbereiner, J. 2000. Influence of nitrogen fertilization on the population of diazotrophic Herbaspirillum spp. and Gluconacetobacter diazotrophicus in sugarcane (Saccharum spp.) Plant and Soil 219: 153-159.

Ribeiro, N.V.D.S.; Vidal, M.S.; Barrios, S.C.L.; Baldani, V.L.D.; Baldani, J.I. 2020. Genetic diversity and growth promoting characteristics of diazotrophic bacteria isolated from 20 genotypes of Brachiaria spp. Plant and Soil 451: 187-205.

Rooney, A.P.; Dunlap, C.A.; Flor-Weiler, L.B. 2016. Acinetobacter lactucae sp. nov., isolated from iceberg lettuce (Asteraceae: Lactuca sativa). International Journal of Systematic and Evolutionary Microbiology 66: 3566-3572.
Sasirekha, B.; Srividya, S. 2016. Siderophore production by Pseudomonas aeruginosa FP6, a biocontrol strain for Rhizoctonia solani and Colletotrichum gloeosporioides causing diseases in chilli. Agriculture and Natural Resources 50: 250-256

Sawar, M.; Kremer, R.J. 1995. Determination of bacterially derived auxins using a microplate method. Letters in Applied Microbiology 20: 282-285.

Schloter, M.; Assmus, B.; Hartmann, A. 1994. The use of immunological methods to detect and identify bacteria in the environment. Biotechnology Advances 13: 75-90.

Sharifi, R.; Lee, S.M.; Ryu, C.M. 2018. Microbe-induced plant volatiles. New Phytologist 220: 684-691.

Sharma, S.B.; Sayyed, R.Z.; Trivedi, M.H.; Gobi, T.A. 2013. Phosphate solubilizing microbes: a sustainable approach for managing phosphorus deficiency in agricultural soils. Springer Plus 2: 587.

Souza, M.S.T.; Baura, V.A.; Santos, S.A.; Fernandes-Junior, P.I.; Reis Junior, F.B.; Paggi, G.M.; Brasil, M.S. 2017. Azospirillum spp. from native forage grasses in Brazilian Pantanal floodplain: biodiversity and plant growth promotion potential. World Journal of Microbiology \& Biotechnology 33: 81.

Souza, R.S.C.; Okura, V.K.; Armanhi, J.S.L.; Jorrín, B.; Lozano, N.; Silva, M.J.; González-Guerreiro, M.; Araújo, L.M.; Verza, N.C.; Bagheri, H.C.; Imperial, J.; Arruda, P. 2016. Unlocking the bacterial and fungal communities assemblages of sugarcane microbiome. Scientific Reports 6: 28774.

Tamura, K.; Stecher, G.; Peterson, D.; Filipski, A.; Kumar, S. 2013. MEGA6: molecular evolutionary genetics analysis version 6.0. Molecular Biology and Evolution 30: 2725-2729.

Teixeira, P.; Colaianni, N.; Fitzpatrick, C.; Dangl, J. 2019. Beyond pathogens: microbiota interactions with the plant immune system. Current Opinion in Microbiology 49: 7-17.

Tortora, M.L.; Díazricci, J.C.; Pedraza, R. 2011. Azospirillum brasilense siderophores with antifungal activity against Colletotrichum acutatum. Archives of Microbiology 193: 275-286.

United States Department of Agriculture [USDA]. 2020. Foreign Agricultural Service. Available at: http://apps.fas.usda.gov/ psdonline/ [Accessed Aug 4, 2020]

Van Deynze, A.; Zamora, P.; Delaux, P.M.; Heitmann, C.; Jayaraman, D.; Rajasekar, S.; Graham, D.; Maeda, J.; Gibson, D.; Schwartz, K.D.; Berry, A.M.; Bhatnager, S.; Jospin, G.; Bennett, A.L. 2018. Nitrogen fixation in a landrace of maize is supported by a mucilage-associated diazotrophic microbiota. PLOS Biology 16: e2006352.

Vassileva, M.; Azcon, R.; Barea, J.M.; Vasslev, N. 2000. Rock phosphate solubilization by free and encapsulated cells of Yarowiali polytica. Process Biochemistry 35: 693-700.

Videira, S.S.; Oliveira, D.M.; Morais, R.F.; Borges, W.L.; Baldani, V.L.D.; Baldani, J.I. 2012. Genetic diversity and plant growth promoting traits of diazotrophic bacteria isolated from two Pennisetum purpureum Schum. genotypes grown in the field. Plant and Soil 356: 51-66.

Wang, R.F.; Cao, W.W.; Cerniglia, C.E. 1996. Phylogenetic analysis of Fusobacterium prausnitzii based upon 16S rRNA gene sequence and PCR confirmation. International Journal of Systematic Bacteriology 46: 341-343.

$\mathrm{Wu}, \mathrm{H}$. 2005. Identification and characterization of a novel biotin synthesis gene in Saccharomyces cerevisiae. Applied Environmental Microbiology 71: 45-55. 